\title{
Clay Mineralogy and Geochemistry of Shales from the Paleoproterozoic Kaladgi Basin, Dharwarn Craton, Southern India: Implications on Provenance and Paleoweathering conditions
}

\author{
PRONOY ROY ${ }^{1}$, BULUSU SREENIVAS ${ }^{1}$ AND
} GOPALAKRISHNARAO PARTHASARATHY ${ }^{2}$

${ }^{1}$ CSIR-National Geophysical Research Institute

${ }^{2}$ National Institute of Advanced Studies

Presenting Author: r.starpro0009@gmail.com

The Proterozoic witnessed fundamental changes such as the Great Oxidation Event (GOE; 2.45 and $2.32 \mathrm{Ga}$ ), followed by the Lomagundi Event (LE) of high $\delta^{13} \mathrm{C}$ excursion (2.22 to $2.06 \mathrm{Ga}$ ), and global orogeny (2.06 to $1.78 \mathrm{Ga}$ ) leading to the formation of Nuna Supercontinent. Finally, the formation of unmetamorphosed shallow-marine sedimentary basins (1.8-1.6 $\mathrm{Ga}$, and extending known as the Statherian) marks the end of the Paleoproterozoic. It is essential to understand the changes that ensued during the Statherian for unraveling the dramatic events that shaped the beginning of the Paleoproterozoic. The northern and the eastern margins of the Meso- to Neoarchean Dharwar craton of south India witnessed the development of such endPaleoproterozoic sedimentary basins (Kaladgi and Cuddapah). In this work, we attempt to reconstruct the provenance and weathering history of sediments from the Paleoproterozoic Kaladgi basin. The Kaladgi basin is mostly dominated by siliciclastics and platformal carbonate sediments lying above the Archean basement. The U-Pb baddeleyite age of $1861 \pm 4 \mathrm{Ma}$ (Joy et al., 2019) intruding the lower formations assigns a Statherian age. The XRD, FTIR (Spectroscopy), DTA (Differential Thermal Analysis), TG (Thermogravimetrtic), XRF, ICP-MS studies on shales from various formations were carried out to characterize the phyllosilicates. We found that illite, montmorillonite, and chlorite dominate shales belonging to lower formations, whereas kaolinite in the upper ones indicating a change in the provenance. The IC index (illite crystallinity index) suggests Kaladgi shales experienced $<350{ }^{\circ} \mathrm{C}$ temperature and low pressure pointing towards Anchi-epimetamorphism.

Major element oxide, Trace element, and REE compositions indicate that lower formation shales are enriched in $\mathrm{Fe}_{2} \mathrm{O}_{3}, \mathrm{MgO}$, $\mathrm{Cr}, \mathrm{Ni}, \mathrm{Co}$, while the upper shales in $\mathrm{Ba}, \mathrm{Th}, \mathrm{Zr}$, and LILE corroborating a provenance change. The shales record high premetasomatic CIA values indicating enhanced greenhouse conditions and chemical weathering during these Statherian sediments' deposition.

Joy, S., Patranabis-Deb, S., Saha, D., Jelsma, H., Maas, R., Söderlund, U. and Krishnan, U. (2019) Depositional history and provenance of cratonic "Purana" basins in southern India: A multipronged geochronology approach to the Proterozoic Kaladgi and Bhima basins. Geological Journal, 54(5), 29572979. 